Результаты исследования свидетельствуют о том, что клетки, выделенные из жировой ткани, способны к специфическому дифференцированию, а именно в остеогенном, хондрогенном и адипогеном направлениях, что является свидетельством мультипотентности мезенхимальных стволовых клеток жировой ткани.

Жировая ткань является альтернативой костному мозгу, как источнику мультипотентных мезенхимальных стволовых клеток, которые могут быть использованы для дальнейших исследований по изучению возможностей использования стволовых клеток в качестве защиты пересаженной, путем липофилинга автологической жировой ткани от тканевой резорбции.

Ключевые слова: жировая ткань, стволовые клетки, дифференциация.

\title{
DIRECTED DIFFERENTIATION OF STEM CELLS THAT ARE ISOLATED FROM THE ADIPOSE TISSUE
}

\section{Yu.V. Poliachenko, E.M. Zapol's'ka, R.V. Saliutin}

Abstract. The authors have carried out an experimental study for the purpose of determining a possibility of differentiating stem cells that are isolated from the adipose tissue according to the adipogenic orientation. The results of the research were indicative of the fact that the cells isolated from the adipose tissue are of specific differentiation, namely, an osteogenic, chondrogenic and, above all, adipogenic orientation that is an evidence of the multipotency of the stem mesenchymal cells of the adipose tissue. The adipose tissue is an alternative source to the bone marrow of multipotent mesenchymal stem cells that can be used as a protection of transplanted autologous adipose tissue from resorption by lipofilling.

Key words: adipose tissue, stem cell, differentiation.

SI "National Institute of Surgery and Transplantology" Named after O.O. Shalimov of Ukraine's NAMS (Kyiv) Coordinating Center for Transplantation of Organs, Tissues and Cells of Ukraine's MHP

Buk. Med. Herald. - 2013. - Vol. 17, № 1 (65). - P. $92-96$

(c) Ю.В. Поляченко, Е.М. Запольська, Р.В. Салютін, 2013

УДК 616-001.3/5-06:616-092.19-085.212]-092.9

\section{С.М. Придруга ${ }^{1}$ Р.М. Борис ${ }^{2}$ \\ ПОРУШЕННЯ ГУМОРАЛЬНОЇ ЛАНКИ ІМУНІТЕТУ В ПЕРІОД ПІЗНІХ ПРОЯВІВ ПОЛІТРАВМИ ТА ЙОГО КОРЕКЦІЯ ТІОТРИАЗОЛІНОМ}

\footnotetext{
1 ДВНЗ “Тернопільський державний медичний університет імені І.Я. Горбачевсього”,

${ }^{2}$ ДП “Український науково-дослідний інститут медицини транспорту МОЗ України”, м. Одеса
}

\begin{abstract}
Резюме. Політравма в періоді пізніх проявів травматичної хвороби супроводжується вираженими порушеннями гуморального імунітету, які проявляються збільшенням вмісту в сироватці крові циркулюючих імунних комплексів (ЦІК) та імуноглобулінів класів А, M, G на 14-28-му доби експерименту. Застосування тіотриазоліну супроводжується меншим напруженням
\end{abstract}

Вступ. Синдром поліорганної недостатності - типове ускладнення тяжкої механічної травми та травматичної хвороби (ТХ). В основі його розвитку лежить порушення кровотоку в мікроциркуляторному руслі з розвитком системної гіпоксіі, у результаті чого відбувається активація цитокінової продукції клітинами моноцитарномакрофагальної системи. Це, у свою чергу, призводить до значних порушень в імунній системі, в основному іiі пригнічення, наслідком чого стає розвиток нозокоміальних інфекцій [2].

Період пізніх проявів політравми (після 14 діб з моменту травми) характеризується активацією репаративних і відновних процесів. У цей період також реалізуються наслідки інфекційних ускладнень [3]. Однак особливості реагування (c) С.М. Придруга, Р.М. Борис, 2013 гуморального імунітету, що супроводжувалося статистично достовірно нижчим вмістом у сироватці крові ЦІК, Ig A, M, G стосовно нелікованих тварин у всі терміни спостереження.

Ключові слова: політравма, гуморальний імунітет, тіотриазолін.

гуморальної ланки імунітету у відповідь на експериментальну політравму в період пізніх проявів TX вивчені недостатньо. Немає даних щодо корекції імунної відповіді тіотриазоліном - поліфункціональним препаратом, здатним нівелювати ряд патогенних механізмів, притаманних тяжкій травмі, у тому числі й порушення імунітету [8]. В умовах політравми доведений його позитивний ефект у період ранніх проявів політравми [4].

Мета роботи. 3'ясувати особливості порушень гуморальної ланки імунітету в період пізніх проявів політравми та ефективність його корекції тіотриазоліном.

Матеріал і методи. В експериментах використано 54 нелінійних білих щурів-самців масою 200-220 г, які утримувалися в стандартних умо- 
вах віварію. Усіх тварин розподілили на три групи: контрольну (6 інтактних тварин) та дві дослідних (по 24 тварини). У першій дослідній групі моделювали політравму й внутрішньочеревно уводили фізіологічний розчин в еквівалентній до основного лікувального препарату дозі; у другій дослідній групі моделювали політравму і проводили корекцію шляхом внутрішньочеревного уведення тіотриазоліну фірми “Артеріум" (Україна) у вигляді 2,5 \% розчину в дозі 9,07 мг·кг ${ }^{-1}$, яка відповідала середньодобовій дозі 100 мг для дорослої людини [5]. Препарати уводили одноразово в один і той самий час у першій половині дня. Курс уведення складав 7 днів: 3 7-ї до 14-ї доби посттравматичного періоду.

Політравму моделювали в умовах тіопентало-натрієвого наркозу (40 мг×кг $\left.{ }^{-1}\right)$, дозованим ударом по кожному стегну спеціально розробленим пристроєм до досягнення перелому. Тварин умертвляли в умовах тіопентало-натрієвого знечуленням шляхом тотального кровопускання 3 серця через 14, 21 і 28 діб після нанесення політравми, що відповідало періоду пізніх проявів травматичної хвороби [3].

У сироватці крові піддослідних тварин визначали концентрацію імуноглобулінів класів А, M, G (Igg A, M, G) із застосуанням наборів реактивів "Нuman" (Німеччина) та концентрацію циркулюючих імунних комплексів (ЦІК) за методикою Ю.Я. Гриневича і співавт. (1981) [1]. Усі експерименти виконано із дотриманням загальних правил і положень Свропейської Конвенції із захисту хребетних тварин, які використовуються для дослідницьких та інших наукових цілей (Страсбург, 1986), Загальних етичних принципів експериментів на тваринах (Київ, 2001), Закону України "Про захист тварин від жорстокої поведінки" (2006), а також згідно 3 "Науковопрактичними рекомендаціями 3 утримання лабораторних тварин та роботи з ними" [7].

Одержаний цифровий матеріал обробляли методом варіаційної статистики з використанням критерію Стьюдента.

Результати дослідження та їх обговорення. У відповідь на політравму (табл., рис. 1-4) на 14-ту добу суттєво вищим виявився вміст ЦІК та імуноглобулінів класів A, M, G у сироватці крові. Стосовно контрольної групи величини даних показників виявилися більшими відповідно на $22,1,63,5,30,5$ і $69,6 \%$ (p<0,001).

На 21-шу добу відмічалося статистично достовірне збільшення величин досліджуваних показників гуморального імунітету. Стосовно 14-ї доби спостереження вміст у сироватці крові ЦІК збільшився на 58,6 \% (p£0,05), Ig A - на 17,5\% (p£0,05), $\operatorname{Ig} \mathrm{M}$ - на 5,3\% (p£0,05), Ig G - на 8,7 \% (p£0,05).

На 28-му добу вміст у сироватці крові ЦІК статистично достовірно знижувався стосовно попереднього терміну спостереження - на 7,9 \% ( $\leq \leq 0,05)$, вміст Ig A та Ig М залишалися на попередньому рівні, а вміст Ig $\mathrm{G}$ суттєво підвищувався (на $12,7 \%, \mathrm{p} \leq 0,05)$.
Таким чином, політравма у віддаленому періоді супроводжується вираженими порушеннями гуморального імунітету, які проявляються збільшенням вмісту в сироватці крові ЦІК та імуноглобулінів класів A, M, G на 14-ту добу експерименту з наступним збільшенням на 21-шу добу. На 28-му добу вміст ЦІК знижується, вміст Ig A, Ig M залишається на попередньому рівні, а вміст Ig G суттєво зростає.

Після застосування тіотриазоліну на 14-ту добу експерименту вміст у сироватці крові досліджуваних показників гуморального імунітету виявився статистично достовірно нижчим, ніж у нелікованих тварин: ЦІК - на 13,0 \% ( $<<0,001)$, Ig А - на 23,1\%(p<0,001), Ig M - на 9,1\%(p<0,01), $\operatorname{Ig} \mathrm{G}-$ на $36,0 \%(\mathrm{p}<0,001)$. Стосовно контрольної групи більшість показників гуморального імунітету були суттєво більшими ( $<00,05-0,001)$ за виключенням вмісту ЦІК, який мав лише тенденцію до більшої величини (на $6,3 \%, \mathrm{p}<0,10)$.

На 21-шу добу відмічалося статистично достовірне зростання досліджуваних показників порівняно з попереднім терміном спостереження: ЦІК - на 56,1 \% (p $\leq 0,05)$, Ig A - на 28,7 \% (p $\leq$ $0,05), \operatorname{Ig} \mathrm{M}-$ на $9,3 \%$ (p $\leq 0,05), \operatorname{Ig} \mathrm{G}-$ на $50,1 \%$ (p $\leq 0,05)$. Їх рівень у цей термін спостереження виявився істотно меншим, ніж у нелікованих тварин: відповідно на $14,4 \%(\mathrm{p}<0,01), 15,8 \%$ $(\mathrm{p}<0,001), 5,6 \%(\mathrm{p}<0,05), 11,7 \%(\mathrm{p}<0,01)$.

На 28-му добу вміст у сироватці крові лікованих тварин ЦІК статистично достовірно знижувався стосовно попереднього терміну спостереження (на $31,2 \%, \mathrm{p} \leq 0,05$ ) й досягав рівня 14-ї доби спостереження. Аналогічно знижувався й вміст Ig А (на 23,4 \%, p $\leq 0,05)$. У свою чергу, вміст у сироватці крові Ig М на 28-му добу в лікованих тварин теж знижувався стосовно 21-ї доби спостереження (на 17,4 \%, $\mathrm{p} \leq 0,05$ ), проте ставав меншим від рівня 14-ї доби $(\mathrm{p} \leq 0,05)$. Вміст у сироватці крові Ig $\mathrm{G}$ теж понижувався стосовно 21-ї доби (на 20,6 \%, p $\leq 0,05$ ), проте не досягав рівня 14-ї доби, залишався істотно вищим (на $19,1 \%, \mathrm{p} \leq 0,05)$.

Всі досліджувані показники гуморального імунітету у тварин, які отримували тіотриазолін, на 28-му добу виявилися істотно меншими, ніж у нелікованих тварин: ЦІК - на 36,0 \% (p<0,001), Ig А - на $32,4 \%(\mathrm{p}<0,001)$, Ig $\mathrm{M}$ - на $18,3 \%$ $(\mathrm{p}<0,001), \operatorname{Ig} \mathrm{G}-$ на $37,6 \%(\mathrm{p}<0,001)$.

Таким чином, застосування тіотриазоліну супроводжується меншим напруженням гуморального імунітету, що супроводжується статистично достовірно нижчим вмістом у сироватці крові ЦІК, Ig A, M, G стосовно нелікованих тварин у всі терміни спостереження періоду пізніх проявів ТХ.

Отримані результати свідчать про те, що в лабораторних тварин через 14 діб після перелому обох стегон не відмічається суттєвого зниження імунної відповіді: суттєво підвищеними залишається вміст імуноглобулінів та ЦІК. У подальшому привертає увагу суттєве збільшення Ig A імуноглобуліну локалізованого переважно на 
Таблиця

Вміст ЦІК та імуноглобулінів I, M, G сироватки крові в динаміці періоду пізніх проявів травматичної хвороби $(\mathrm{M} \pm \mathrm{m})$

\begin{tabular}{|c|c|c|c|c|c|}
\hline \multirow{2}{*}{ Показник } & \multirow{2}{*}{ Умови досліду } & \multirow{2}{*}{ Контроль } & \multicolumn{3}{|c|}{ Політравма } \\
\hline & & & 14-та доба & 21-ша доба & 28-ма доба \\
\hline \multirow[b]{2}{*}{ ЦІК, ум.од. } & Не ліковані & \multirow{2}{*}{$\begin{array}{c}88,67 \pm \\
2,32\end{array}$} & $108,3 \pm 1,2^{* * * *}$ & $171,8 \pm 2,7^{* * *}$ & $158,2 \pm 2,2^{* * *}$ \\
\hline & Тіотриазолін & & $94,25 \pm 1,54^{\#}$ & $147,1 \pm 5,6^{* * *}$ & $\begin{array}{c}101,2 \pm \\
3,1^{* * *}\end{array}$ \\
\hline \multicolumn{3}{|c|}{$\mathrm{p}$} & $<0,001$ & $<0,01$ & $<0,001$ \\
\hline \multirow{2}{*}{$\operatorname{Ig} \mathrm{A}, \Gamma^{\times} \mathrm{J}^{-1}$} & Не ліковані & \multirow{2}{*}{$\begin{array}{c}0,537 \pm \\
0,023\end{array}$} & $\begin{array}{c}0,878 \pm \\
0,015^{* * *}\end{array}$ & $1,032 \pm 0,022^{* * *}$ & $\begin{array}{c}0,985 \pm \\
0,035^{* * *}\end{array}$ \\
\hline & Тіотриазолін & & $\begin{array}{c}0,675 \pm \\
0,011^{* * *}\end{array}$ & $0,869 \pm 0,024^{* * *}$ & $\begin{array}{c}0,666 \pm \\
0,019^{* * * *}\end{array}$ \\
\hline \multicolumn{3}{|c|}{$\mathrm{p}$} & $<0,001$ & $<0,001$ & $<0,001$ \\
\hline \multirow{2}{*}{$\operatorname{Ig} \mathrm{M}, \Gamma^{\times} \mathrm{J}^{-1}$} & Не ліковані & \multirow{2}{*}{$\begin{array}{c}0,919 \pm \\
0,008\end{array}$} & $\begin{array}{c}1,199 \pm \\
0,009^{* * * *}\end{array}$ & $\begin{array}{c}1,263 \pm \\
0,026^{* * * *}\end{array}$ & $\begin{array}{l}1,205 \pm \\
0,036^{* * *}\end{array}$ \\
\hline & Тіотриазолін & & $\begin{array}{c}1,090 \pm \\
0,027^{* * *}\end{array}$ & $\begin{array}{c}1,192 \pm \\
0,007^{* * *}\end{array}$ & $\begin{array}{c}0,984 \pm \\
0,008^{* * *}\end{array}$ \\
\hline \multicolumn{3}{|c|}{$\mathrm{p}$} & $<0,01$ & $<0,05$ & $<0,001$ \\
\hline \multirow{2}{*}{$\operatorname{Ig~G}, \Gamma^{\times} \mathbb{J}^{-1}$} & Не ліковані & \multirow{2}{*}{$\begin{array}{c}1,671 \pm \\
0,051\end{array}$} & $\begin{array}{c}2,834 \pm \\
0,068^{* * *}\end{array}$ & $\begin{array}{c}3,081 \pm \\
0,048^{* * *}\end{array}$ & $\begin{array}{c}3,473 \pm \\
0,024^{* * *}\end{array}$ \\
\hline & Тіотриазолін & & $\begin{array}{l}1,814 \pm \\
0,030^{*}\end{array}$ & $\begin{array}{c}2,722 \pm \\
0,088^{* * *}\end{array}$ & $\begin{array}{c}2,161 \pm \\
0,072^{* * *}\end{array}$ \\
\hline \multicolumn{3}{|c|}{$\mathrm{p}$} & $<0,001$ & $<0,01$ & $<0,05$ \\
\hline
\end{tabular}

Примітка. 1. ${ }^{*, \#}$ - достовірність відмінностей стосовно контрольної групи $\left({ }^{*}-\mathrm{p}<0,05 ;{ }^{* *}-\mathrm{p}<0,01 ;{ }^{* * *}-\mathrm{p}<0,001 ;{ }^{\#}-\right.$ $\mathrm{p}<0,10) ; 2$. $\mathrm{p}$ - достовірність відмінностей між показниками нелікованих і лікованих тіотриазоліном тварин; 3 . ЦІК циркулюючі імунні комплекси

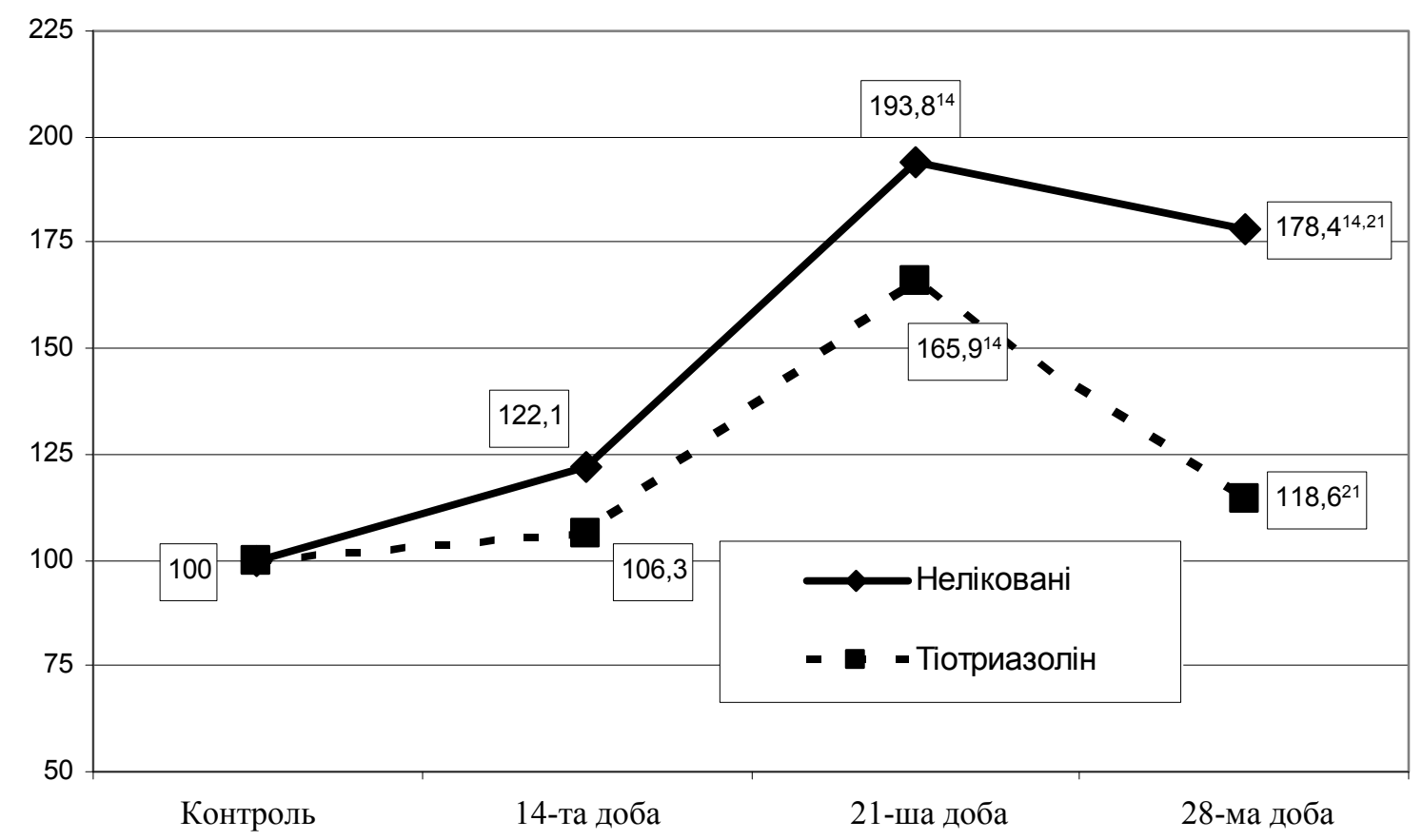

Рис. 1. Ступінь відхилення вмісту ЦІК у сироватці крові (у відсотках стосовно контролю) у період пізніх проявів травматичної хвороби та його корекція тіотриазоліном

(Тут і на інших рисунках: $:^{14,21}$ - відмінність стосовно 14-ї і 21-ї доби спостереження статистично достовірна: $\mathrm{p} \leq 0,05$ ); ЦІК - циркулюючі імунні комплекси) 


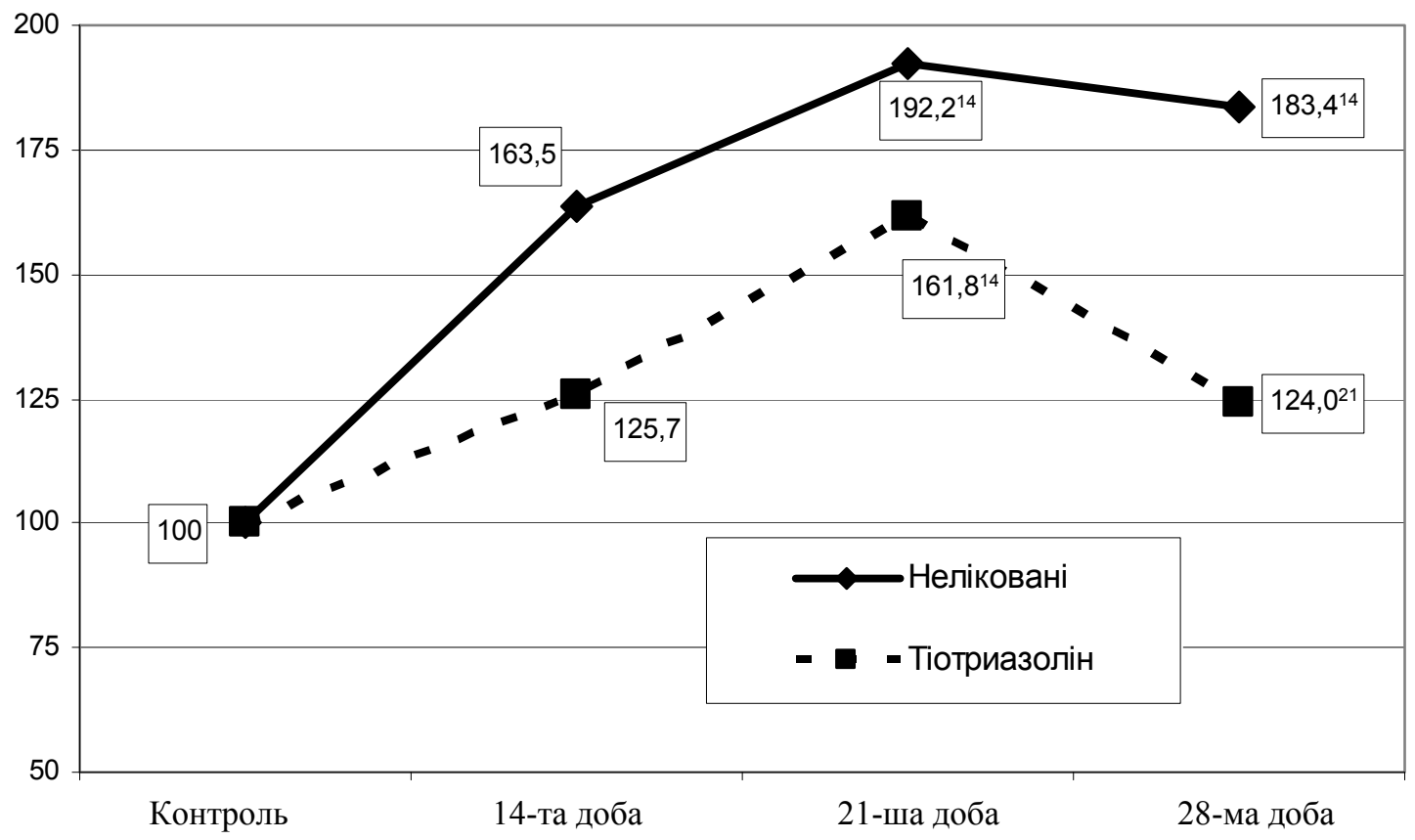

Рис. 2. Ступінь відхилення вмісту Ig А у сироватці крові (у відсотках стосовно контролю) у період пізніх проявів травматичної хвороби та його корекція тіотриазоліном

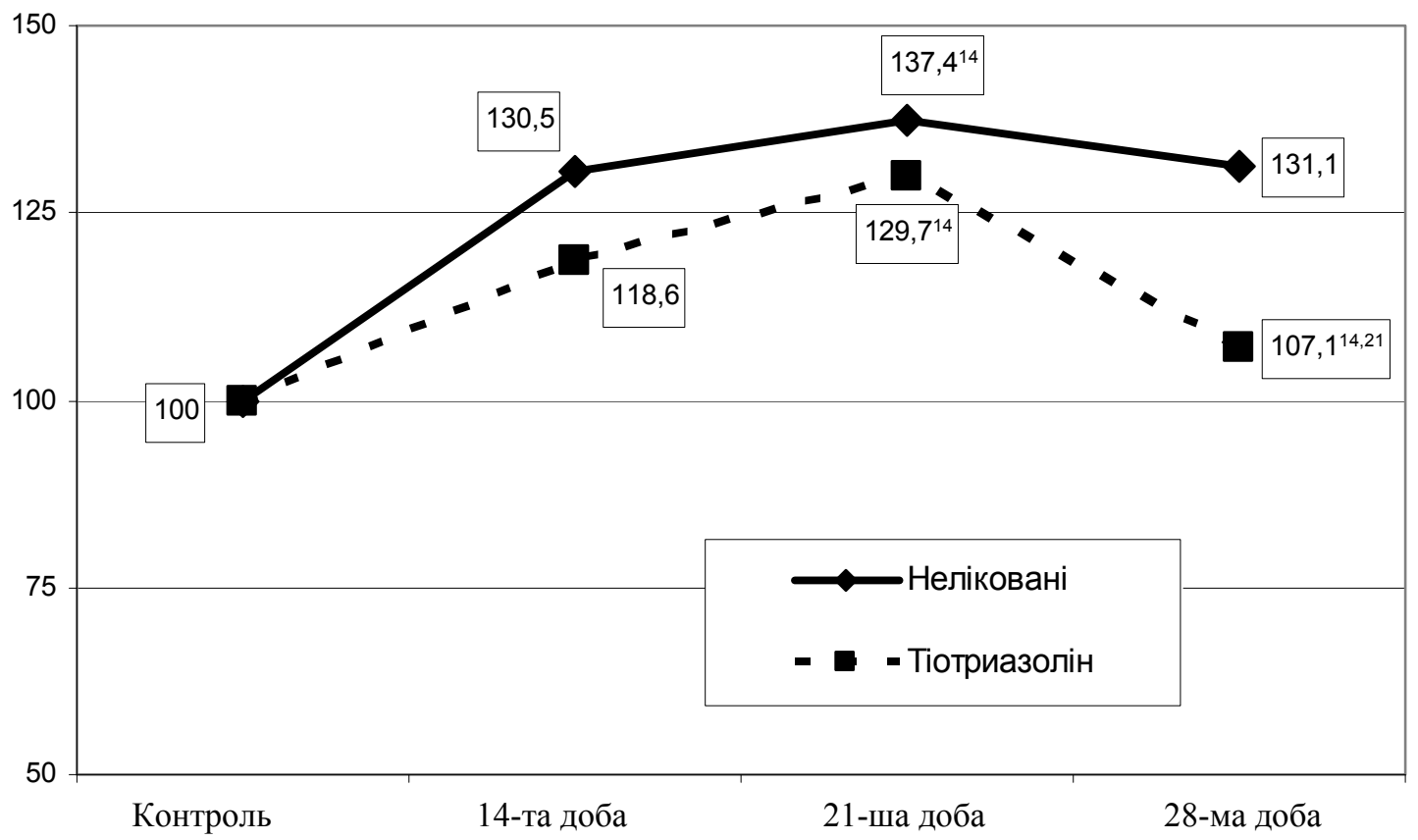

Рис. 3. Ступінь відхилення вмісту Ig М у сироватці крові (у відсотках стосовно контролю) у період пізніх проявів травматичної хвороби та його корекція тіотриазоліном

слизових оболонках, що вказує на можливість дисбактеріальних порушень на слизових оболонках, зокрема кишок, оскільки транслокація мікрофлори є одним із характерних ускладнень системної відповіді організму на запалення. Також стрімко збільшується до 28-ї доби вміст Ig G та 3 21-ї доби зменшується вміст Ig M, що належить до характерних особливостей динаміки продуктивної фази синтезу антитіл. Привертає увагу також і феномен загострення, який має місце на 21-шу добу, що відповідає сучасним експериментальним даним щодо перебігу періоду пізніх проявів політравми [8]. Проте у всі терміни спосте- реження вміст досліджуваних імуноглобулінів та ЦІК у сироватці крові істотно перевищує контрольний рівень, що вказує на істотне напруження імунної відповіді. У цих експериментальних умовах суттєво знижуються величини досліджуваних показників у всі терміни спостереження, менш вираженою є амплітуда відхилень в умовах загострення перебігу травматичної хвороби. Отриманий результат свідчить про корегувальний вплив тіотриазоліну, який, очевидно, реалізується через його антиоксидантну, мембранопротекторну, метаболічну, антигіпоксичну, антитоксичну дію , що дозволяє рекомендувати даний препарат у 


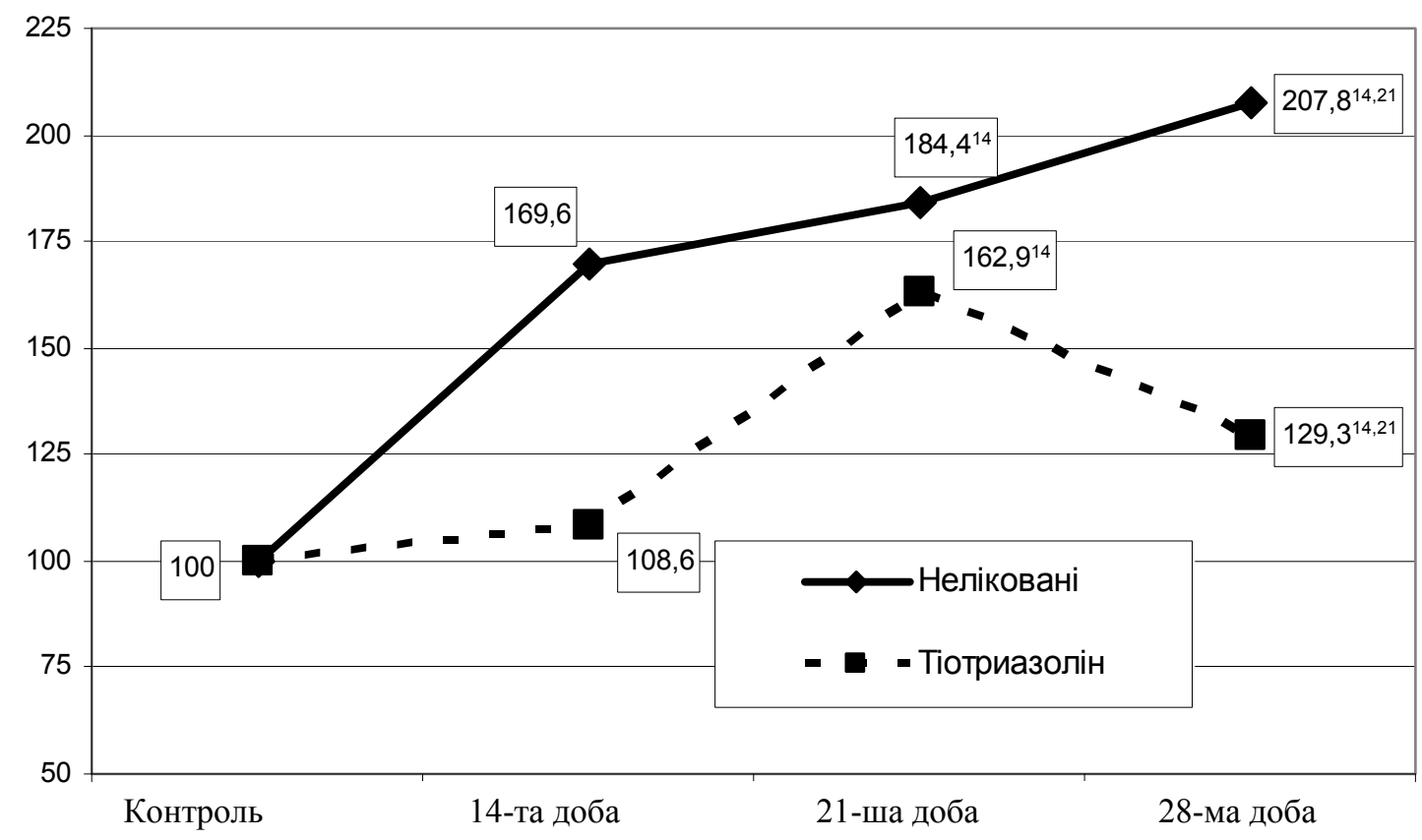

Рис. 4. Ступінь відхилення вмісту Ig G у сироватці крові (у відсотках стосовно контролю) у період пізніх проявів політравми та його корекція тіотриазоліном

комплексній інтенсивній терапії травматичної хвороби.

\section{Висновки}

1. Політравма у періоді пізніх проявів травматичної хвороби супроводжується вираженими порушеннями гуморального імунітету, які проявляються збільшенням вмісту в сироватці крові ЦІК та імуноглобулінів класів А, M, G на 14-ту добу експерименту з наступним збільшенням на 21-шу добу. На 28-му добу вміст ЦІК знижується, вміст Ig A, Ig М залишається на попередньому рівні, а вміст Ig G суттєво зростає.

2. Застосування тіотриазоліну супроводжується меншим напруженням гуморального імунітету, що супроводжувалося статистично достовірно нижчим вмістом у сироватці крові ЦІК, Ig A, M, G стосовно нелікованих тварин у всі терміни спостереження пізнього періоду проявів травматчиної хвороби.

Перспективи подальших досліджень. У подальшому необхідно дослідити ефективність тіотриазоліну з використанням інших експериментальних моделей політравми, що розширить доказову базу його ефективності на доклінічному рівні.

\section{Література}

1. Гриневич Ю.А. Определение иммунных комплексов в крови онкологических больных / Ю.А. Гриневич, А.М. Алферов // Лаб. дело. 1981. - № 8. - C. 493-495.
2. Дзюба Д.А. Особенности иммунного ответа у пострадавших с тяжелой политавмой / Д.А. Дзюба, И.Р. Малыш, Л.В. Згржебловская // Укр. мед. альманах. - 2008. - Т. 11, № 1 (додаток). - С. 172-174.

3. Ельский В.Н. Моделирование черепномозговой травмы / В.Н. Ельский, С.В. Зяблицев. - Донецк: Изд-во “Новый мир”, 2008. $140 \mathrm{c}$.

4. Использование тиотриазолина в раннем периоде травматической болезни / В.Н. Ельский, С.В. Пищулина, М.С. Кишеня [и др.] // Питання експерим. та клін. мед. - 2011. - Т. 1, вип. 15. - С. 110-112.

5. Клиническое применение тиотриазолина в терапии / И.А. Мазур, Н.А. Волошин, И.С. Чекман [и др.] // Сучасна гастроентерологія. - 2006. - № 1. - С. 71-74.

6. Козак Д. В. Динаміка показників цитолізу в умовах політравми / Д.В. Козак // Шпит. хірургія. - 2012. - № 2. - С. 50-52.

7. Науково-практичні рекомендації з утримання лабораторних тварин та роботи 3 ними / [Ю.М. Кожем'якін, О.С. Хромов, М.А. Філоненко, Г.А. Сайфетдінова]. - К.: Авіцена, 2002. $-156 \mathrm{c}$.

8. Тиотриазолин: фармакологические аспекты и клиническое применение / И.А. Мазур, Н.А. Волошин, И.С. Чекман [и др.]. - Запорожье, 2005. - 160 с. 


\title{
НАРУШЕНИЕ ГУМОРАЛЬНОГО ЗВЕНА ИММУНИТЕТА В ПЕРИОД ПОЗДНИХ ПРОЯВЛЕНИЙ ТРАВМАТИЧЕСКОЙ БОЛЕЗНИ И ЕГО КОРРЕКЦИЯ ТИОТРИАЗОЛИНОМ
}

\author{
С.М. Придруга, Р.Н. Борис
}

Резюме. Политравма в период поздних проявлений травматической болезни сопровождается выраженными нарушениями гуморального иммунитета, которые проявляются увеличением содержания в сыворотке крови циркулирующих иммунных комплексов и иммуноглобулинов классов A, M, G на 14-28-ые сутки эксперимента. Применение тиотриазолина сопровождается меньшим напряжением гуморального иммунитета, что сопровождается статистически достоверно низким содержанием в сыворотке крови ЦИК, Ig A, M, G относительно нелеченных животных во все сроки наблюдения.

Ключевые слова: политравма, гуморальный иммунитет, тиотриазолин.

\section{A VIOLATION OF THE HUMORAL COMPONENT OF IMMUNITY DURING THE PERIOD OF LATE MANIFESTATIONS OF WOUND DYSTROPHY AND ITS CORRECTION BY THIOTRIAZOLINE}

\section{S.M. Prydruha, R.M. Borys}

Abstract. Polytrauma during the period of late manifestations of wound dystrophy is accompanied by marked disturbances of the humoral immunity, manifested by an increasing content of blood serum circulating immune complexes (CIC) and immunoglobulin of classes A, M, G in serum on the 14th-28th day of the experiment. The application of thiotriazoline is accompanied by a lesser tension of humoral immunity, which was accompanied by a statistically significantly lower blood serum content of CIC, Ig A, M, G, regarding untreated animals during all periods of observation.

Key words: polytrauma, humoral immunity, thiotriazoline

SHEE "State Medical University Named by I.Ya. Gorbachevsky" (Ternopil), SM "Ukrainian Scientific-Research Institute of Transport Medicine Ministry of the Health of Ukraine" (Odesa)

\section{ЗМІНИ ЕНДОТЕЛІОЦИТІВ КАПІЛЯРІВ ТА ГІСТОЛОГІЧНОЇ СТРУКТУРИ ІШЕМІЗОВАНОЇ ТА ІНТАКТНОЇ М'ЯЗОВОЇ ТКАНИНИ ПІСЛЯ ТРАНСПЛАНТАЦЇ̈ ГЕМОПОЕТИЧНИХ СТОВБУРОВИХ КЛІТИН ФЕТАЛЬНОЇ ПЕЧІНКИ ЛЮДИНИ В ЕКСПЕРИМЕНТІ IN VIVО}

Координаційний центр трансплантації органів, тканин і клітин МОЗ України

Резюме. Досліджена в експерименті ультраструктура ендотеліальних клітин капілярів та гістологічна структура м'язової тканини на різних етапах після трансплантації гемопоетичних стовбурових клітин фетальної печінки.

Доведено, що за умов ішемії стовбурові клітини фетальної печінки стимулюють процеси ангіогенезу, а при трансплантації в інтактну м'язову тканину гемопоетичні стовбурові клітини диференціюються в тканинні макрофаги, загалом не порушуючи структури м'язової тканини.

Ключові слова: гемопоетичні стовбурові клітини фетальної печінки, електронна мікроскопія, гістологія.

В останні роки в клінічну практику увійшли методи клітинної терапії, які грунтуються на застосуванні автологічних стовбурових клітин кісткового мозку. Однак широке клінічне використання стовбурових клітин кісткового мозку проблематичне, оскільки процедура їх отримання достатньо складна, а в результаті вдається отри-

(C) Р.В. Салютін, Д.Б. Домбровський, С.С. Паляниця, В.А. Шаблій,

Р.М. Борис, Г.С. Лобинцева, О.В. Буслович, 2013 